\title{
How to Assess the Development of Entrepreneurship Education at University Level \\ The Case of Denmark
}

Moberg, Kåre; Vestergaard, Lene; Jørgensen, Casper; Markussen, Elisabeth; Hakverdyan, Sose

Document Version

Final published version

Publication date:

2013

License

CC BY-NC-ND

Citation for published version (APA):

Moberg, K., Vestergaard, L., Jørgensen, C., Markussen, E., \& Hakverdyan, S. (2013). How to Assess the Development of Entrepreneurship Education at University Level: The Case of Denmark. Institut for Strategic Management and Globalization. SMG Working Paper No. 4/2013

Link to publication in CBS Research Portal

\footnotetext{
General rights

Copyright and moral rights for the publications made accessible in the public portal are retained by the authors and/or other copyright owners and it is a condition of accessing publications that users recognise and abide by the legal requirements associated with these rights.

Take down policy

If you believe that this document breaches copyright please contact us (research.lib@cbs.dk) providing details, and we will remove access to the work immediately and investigate your claim.
}

Download date: 26. Apr. 2023 
HOW TO ASSESS THE DEVELOPMENT OF ENTREPRENEURSHIP EDUCATION AT UNIVERSITY LEVEL

The Case of Denmark

\author{
KÅRE MOBERG \\ LENE VESTERGAARD \\ CASPER JØRGENSEN \\ ELISABETH MARKUSSEN \\ SOSE HAKVERDYAN
}

SMG WP 4/2013

February, 2013 
SMG Working Paper No. 4/2013

February, 2013

ISBN: 978-87-91815-86-7

Department of Strategic Management and Globalization Copenhagen Business School

Kilen, Kilevej 14A

2000 Frederiksberg

Denmark

www.cbs.dk/smg 


\section{HOW TO ASSESS THE DEVELOPMENT OF ENTREPRENEURSHIP EDUCATION AT UNIVERSITY LEVEL}

The case of Denmark

$$
\text { KÅRE MOBERG }
$$

Copenhagen Business School / Danish Foundation for Entrepreneurship - Young Enterprise

\section{LENE VESTERGAARD}

Danish Foundation for Entrepreneurship - Young Enterprise

$$
\text { CASPER JØRGENSEN }
$$

Danish Foundation for Entrepreneurship - Young Enterprise

$$
\text { ELISABETH MARKUSSEN }
$$

Danish Foundation for Entrepreneurship - Young Enterprise

$$
\text { SOSE HAKVERDYAN }
$$

Danish Foundation for Entrepreneurship - Young Enterprise

$$
\text { Prepared for: }
$$

Handbook of Entrepreneurship Education Series: The Entrepreneurial University,

Fayolle, A. \& Redford, D. (eds.), Edward Elgar Publishing Limited, 2013.

September $25^{\text {th }}, 2012$

SMG WP 4/2013

Key words: Entrepreneurship education, entrepreneurial university, evaluation, assessment model JEL codes: A2, H52, I25, L29 


\section{Executive summary}

In this book chapter we describe how Denmark's eight universities have developed their supply of entrepreneurship education during the past three years. The governmental initiatives that aim to promote entrepreneurial universities, and the Danish context, are presented and related to this development. An assessment model of entrepreneurship education which includes the wide scope of dimensions important to education in the topic, such as content dimensions, stages in the entrepreneurial project and pedagogical dimensions is presented. By applying this model we have been able to analyse the strengths and weaknesses in the supply of entrepreneurship education at the eight universities.

The results show that the Danish universities have developed well regarding entrepreneurship education, especially on the pedagogical dimensions which means that more courses are becoming through and for entrepreneurship, rather than about entrepreneurship. The dominance of universities with business schools do, however, suggest that entrepreneurship education in Denmark is far from reaching maturity. Our results also suggest that it is important to focus on how to sustain the supply of entrepreneurship education rather than just invest in new course development. 


\section{Introduction}

The Danish government has during the last decade been focusing on transforming the country's universities into entrepreneurial institutions (Blenker, Dreisler \& Kjeldsen, 2006; OECD, 2008). A large range of state sponsored initiatives has been launched, all with a purpose of supporting various entrepreneurial activities, such as student incubators, tech transfer offices and entrepreneurship programmes (ibid). This is much in line with what has happened in other European countries as the process has been driven by pan-European strategies from the EU level (EC, 2011; Geuna, 2001; Kyvik, 2004). The goal of these governmental strategies has been to adapt the higher educational sector to the changing needs of society and the economy (Etzkowitz, Webster, Gebhardt \& Terra, 2000). Universities today are requested to focus on the diffusion of knowledge and research findings as well as commercialisation of new research. Universities are also, to a larger extent, expected to get their own funding by capitalising on these activities, which is made possible by an increased autonomy for the universities (EC, 2011; Etzkowitz et al., 2000).

The educational activities have proven to play an important role in this process (Gibb, 1987), but these are often less prioritized than more visible investments in infrastructure (Heinonen \& Hytti, 2010; Nygaard, 2010). This is somewhat puzzling as the field of entrepreneurship is recognised to have its roots in educational activities (Brush, Duhaime, Gartner, Stewart, Katz, Hitt, Alvarez, Meyer \& Venkataraman, 2003). According to Katz (2008), we have experienced an immense dissemination of entrepreneurship education into departments outside of the business school, and we are now just beginning to see its effect on the overall entrepreneurial activities of the universities. The educational orientation of universities and student activities has, however, during the last decade been recognised as an important tool for universities to establish industry collaboration and increased overall entrepreneurialism (Davis and Diamond, 1997; Nygaard, 2010). 
In this book chapter we present a study of how the eight universities in Denmark have transformed towards becoming entrepreneurial institutions. The focus is primarily on how these institutions have developed courses and programmes in entrepreneurship education. However, entrepreneurship education does not equal start-up training, especially not seen through the lens of the entrepreneurial university perspective, which recognises a broad scope of activities as being entrepreneurial (Etzkowitz, 2003). As the focus of entrepreneurship education is on skills, competencies and attitudes, activities such as innovation within established organisations is viewed as being equally important as new venture creation (EC 2012, Solomon, 2007). In order to capture the broad scope of entrepreneurship education in an inclusive, yet specific way, we have developed a categorization model which allows us to measure how the universities have developed their entrepreneurship education regarding focus on different type contents and stages in the entrepreneurial project. The model also allows us to capture which types of pedagogical methods are being used. This model's theoretical foundations will be thoroughly described in the following.

\section{Theoretical Framework}

As described in the introduction to this anthology, it is evident that there has been an immense focus on transforming universities into entrepreneurial institutions. The dual process of cutbacks in public funding of universities (Geuna, 2001; Kyvik, 2004; OECD, 2005; UNESCO, 2004) in combination with an increased pressure of dissemination of research results and society's demand on universities to play a more active role in the regional economy, has been a real challenge to many universities (Debackere \& Vaugler, 2005; Etzkowitz, 2003; Etzkowitz, Webster, Gebhardt \& Terra, 2000; OECD, 2001). There are, however, many universities that are not active within research fields with a potential to generate innovations and growth companies (Debackere \& Vaugler, 2005; Jensen, 
Thursby \& Thursby, 2003). Many universities have, thus, chosen different strategies than the typical so called "Stanford Model" (Etzkowitz, 2003); instead of establishing new organisations such as tech transfer offices, incubators and science parks, they have relied on their managements' networking capital and the entrepreneurialism of their researchers in order to establish industry collaboration and retrieve funding from external sources (Davis and Diamond, 1997). What is often forgotten in this process is the role that the educational activities play (Heinonen \& Hytti, 2010; Nygaard, 2010).

In the holistic process of transforming the university into an entrepreneurial institution, the educational activities are of major importance (Etzkowitz, 2003). The students play an important role in building the entrepreneurial culture at universities and connecting their activities to the industry in many different ways, e.g. through practice-based educational activities, internships and, naturally, as employees (Gibb, 2012; Pittaway \& Cope, 2006). The field of entrepreneurship has its roots in teaching (Brush et al., 2003) and entrepreneurship education is thus a natural component of the entrepreneurial university (Heinonen \& Hytti, 2010), as it has been seen to produce new ventures as well as innovative employees (Charney \& Libecap, 2000; Gibb, 1987), but also because entrepreneurship programmes and centres have proven to have a positive effect on industry funding (Zeithaml \& Rice, 1987).

During the past decades, researchers have used many different models in order to measure the development and spread of entrepreneurship education (cf. Katz, 1994, 2003, 2004, 2008; Solomon, 1979, 2007; Solomon \& Fernald 1991; Solomon \& Sollosy, 1977; Solomon, Weaver \& Fernald, 1994; Vesper 1985, 1993; Vesper \& Gartner, 1997). According to Katz (2008), we are reaching consensus within the field regarding what entrepreneurship programmes should contain, but we need better models to capture the wide scope of entrepreneurship education, both regarding the content and the teaching methods. Entrepreneurial activities come in many forms, and if we only 
focus on new venture creation we miss out on many entrepreneurial activities that take place within established firms (Foss \& Klein, 2012; Kuratko, 2005). In the next section we will present our categorization model and how it is based in the broad scope of content and pedagogical dimensions that is included within the field of entrepreneurship education.

How to Measure the Development of Entrepreneurship Education

Our categorization model of entrepreneurship education is developed as a tool to be used in the process of transforming universities into entrepreneurial institutions. The model is based on the systems of innovation literature (Lundvall, 1992; Cooke, 2001) as well as the policy oriented triple helix research (Etzkowitz et al., 2000). These research streams recognize the systemic character of entrepreneurial activities, which do not only include venture creators, but also specialists within other fields such as finance (for example venture capitalists) and law (patent experts, etc.). Our model aims to connect the macro-level (political policy) with the micro-level (student competencies), by focusing on the mezzo-level (university education). In order to assure that universities take a holistic approach to entrepreneurship education and develop students with the various skills needed, we have included four content dimensions (entrepreneurship, intrapreneurship, finance and law) in our model. We have also included the specific pedagogies needed to teach entrepreneurship as well as the different stages that are included in a venture project; as different competencies are needed in each. The model, with its holistic approach to entrepreneurship, will be described more thoroughly in a later part of this chapter, but first we will describe how our systemic-oriented model is anchored in the entrepreneurship literature.

Entrepreneurship education is a topic with a broad scope regarding content and teaching techniques (Brush et al., 2003). Different stages in the venture project require different types of 
activities (Bhave, 1994; Stevenson, Roberts \& Grousbeck, 1985), and depending on industry sector and other types of context, these projects can be very dissimilar and have very different skill requirements (Aldrich \& Baker, 1997; Davidsson \& Wiklund, 2001). Entrepreneurship education can further be divided into two major categories: specialized entrepreneurship courses and courses with integrated entrepreneurial elements (Blenker, Korsgaard, Neergaard and Thrane, 2011). The latter do not have venture creation as their major focus, rather these courses aim to alter the attitudes of the students and strengthen their entrepreneurial competencies in order to make them more employable and oriented towards entrepreneurial activities within established organisations (ibid). It can be said that these courses rather focus on corporate venturing (Block and MacMillan, 1993; Burgelman, 1983, 1984, 1986; Zahra, 1991), or what has lately been termed strategic entrepreneurship (Foss \& Lyngsie, 2011; Hitt, Ireland, Camp \& Sexton, 2001), which within the policy world is often termed intrapreneurship (EC, 2008). Regardless of the focus being on new venture creation or strategic entrepreneurship within established organisations there are common skill demands when it comes to understanding financial and legal issues (Foss \& Klein, 2012). The extent to which this is necessary depends of course on the specific venture activity and the industry sector (Vesper \& McMullen, 1988). Some industries, such as biotech, require a thorough understanding of venture capital and IPR, whereas more mundane venture activities only require very basic financial and legal skills.

The broad scope of knowledge, skills and competencies that a venture process requires has to be taken into account in the course design. The context within which entrepreneurs operate frequently spans over many boundaries (Lazear, 2004, 2005; West, 2003) and is often internationally oriented (Jonsson \& Jonsson, 2002; McDougall \& Oviatt, 2000; McDougall, Shane \& Oviatt, 1994; Rialp, Rialp \& Knight, 2004). The entrepreneur frequently has to take on the role as a "jack-of-all trades" (Lazear, 2004, 2005), that is, he or she has to be able to perform many of 
those activities that are separated by division of labour in larger companies (ibid). A multidisciplinary course design in which the instructors make an effort to situate the content in an international or global context is a fruitful way to cover the complexity of a venture process (Brush et al., 2003; Klapper \& Neergaard, 2012).

In order to navigate effectively in society of today, it is important that you are able to leverage uncertainty and adjust to input signals from the environment (Gibb, 1987). This can only be done through an iterative process in which the information and knowledge is practically applied and tested (Biggs \& Tang, 2007; Loyens, Magda, and Rikers 2008). Entrepreneurship education has always been viewed as a practical topic that needs different pedagogical methods in order to be taught effectively (Johannisson 1991; Kyrö and Niemi 2007; Politis 2005; Sarasvathy 2004). Ideally it should simulate the real life processes of an entrepreneur (Gibb, 2002, 2011; Hannon, 2005; Pittaway \& Cope, 2007). However, this might not always be feasible in all courses (Klepper \& Neergard, 2012). Creative and practically oriented teaching methods is needed in order to infuse entrepreneurial attitudes and mindsets into students, as the students often have adapted to the jobtaker mindset that the university setting typically is oriented towards (Blenker et al., 2011). Mindchanging teaching methods are only possible if the students actively participate and take responsibility and ownership of the learning process, which takes place both within and outside the walls of the university (Biggs \& Tang, 2007). In order to effectively teach entrepreneurship oriented content, there is, thus, much to take into consideration regarding teaching methods. A measurement model that aims to assess the development of entrepreneurship courses should therefore not only be specific and inclusive regarding the course content but also with regard to teaching methods. In the following a categorisation model that satisfies these requirements will be described. 


\section{A Categorisation Model for Entrepreneurship Education}

The model is divided into three main categories: content, teaching methods and stages. On the horizontal axis, the model is divided into eight categories, four content categories and four pedagogical dimensions. The four content categories are: entrepreneurship, intrapreneurship, finance and law. The four pedagogical dimensions are: practical dimensions, student participation, multidisciplinary dimensions and international dimensions. On the vertical axis the model is divided into four different stages that resemble the different stages of the entrepreneurial project: idea, beginning, growth and running. Depending on the focus of the course, it can get a score from 0 to 3 in all these categories. It is, thus, possible to categorize which stage of the venture process the course has its focus as well as which content and teaching methods it focuses on. In figure 1 below, an overview of the model is presented.

[Insert Figure 1 here]

There must be a clear focus on the content and the phase of the venture process in order for a course to get a star in one of the content categories. Two stars means that the course focuses heavily on the topic and three stars means that the course specializes in the topic, both practically and theoretically. The same logic applies to the pedagogical categories, but with some natural differences. In order to get one star, there should be a clear focus on the teaching method, whereas two stars means that it is used in the majority of the teaching situations and three stars requires that the course specializes in this specific teaching method. A course can, however, be categorised with three stars in more than one content and pedagogical category, as it is possible to specialize in more 
than one field and phase of the venture project. In the following sections we will describe thoroughly how each of these categories is assessed.

The Content Dimensions. Assessing the content is a fairly straight forward process. In this part of the text we will describe which type of content that is included in each of our four venture stages.. When it comes to entrepreneurship in the first stage it is about coming up with an idea for a venture. A course that focuses on entrepreneurship in this stage is typically about creativity and involves different idea generation exercises. The content is fairly similar to courses that focus on intrapreneurship, finance and law in this stage. When it comes to intrapreneurship, the focus is on idea generation in established organisations. A course that gets scores in the finance/idea category focuses on the economic sustainability of the idea and when it comes to law, methods such as browsing patent data bases are central.

A course which scores in the entrepreneurship/beginning category typically focuses on the act of starting up a new venture. Marshalling of resources and managing ambiguity is of central importance at this stage (Baron, 2012; Sarasvathy, 2008). The content of the courses are typically on iterations and test of ideas, business planning and presentation skills such as elevator pitching. A course in intrapreneurship in this stage is fairly similar, but the focus is on established organisations as the context. A finance/beginning course focuses on the financial aspects of the activities in this stage, such as the financial analysis and market analysis for the new venture. A course that gets scores in the law category in the beginning stage typically deals with the legal processes of starting a company, how to file a patent, etc.

In the growth stage, much focus is on developing and growing the venture. Internationalisation and employment growth brings managerial as well as legal and financial 
challenges to the table. Courses in this stage often focus on best practice strategies for growth and internationalisation, as well as mass marketing and human resource management.

According to Davidsson (2012), the entrepreneurial activities end when the venture has reached a break-even result. However, when it comes to education in the topic, there are many aspects and dimensions that still can be of interest for the student in the running stage. Continuous innovation, diversification and segmentation as well as serial and portfolio entrepreneurship and exit strategies are typical topics in this stage. In figure 2 an overview of what is included in the content dimensions related to the stage in the entrepreneurial project, is presented.

[Insert Figure 2 here]

The Pedagogical Dimensions. The pedagogical dimensions naturally follow the content dimensions and the stage categories, but there are many different ways to teach this content. Practical dimensions can be taught by either taking the students out of the classroom (e.g. field studies, real projects and interaction with the local industry), or by bringing the practice into the classroom (e.g. guest lectures, case competitions and prototype development). The practice dimension is often related to the student participation dimension. Entrepreneurial activities require proactive students who take an active role as learners rather than a passive role as listeners. A high degree of practical dimension in a course often implies that the students have to take a proactive role in performing the activities and assignments. However, if the practical elements of the course are only provided by guest lectures, the student participation will remain low.

As innovation and new economic activity often take place in the intersection between sectors, and entrepreneurs often perform many different roles, it is important to integrate multidisciplinary 
dimensions in the classroom. Again, this can be performed in many different ways. One possibility is to have students with different disciplinary background, and actively work with their different competencies in the course assignments. Another possibility is that the educational team comes from different disciplinary backgrounds, and actively works to combine their competencies in the classroom.

Our last pedagogical category, international dimensions, can in some ways be seen as a content category. However, as the globalization process is accelerating, it is important to focus on international aspects, regardless of it being entrepreneurship or law that is taught. Entrepreneurs will have to relate to this dimension, either as competition at their home market or when deciding to internationalise their activities. The use of international cases, the focus on the internationalisation process or discussions of new technology that enables "born globals" i.e. companies that internationalise from day one, can be good techniques to teach this dimension. In figure 3 below an overview of our four pedagogical categories is presented.

[Insert Figure 3 here]

\section{Methodology}

The data has been collected on a yearly basis for all universities in Denmark by the organisation the Danish Foundation for Entrepreneurship - Young Enterprise, since 2010. The research team is led by a senior data analyst who has collected similar data by using the model on different universities since 2007. The data collection is performed by browsing of web pages where key words such as entrepreneurship, business planning, intrapreneurship, corporate venturing, innovation, idea 
generation, creativity, and patent (in both Danish and English languages) are searched for. Key personnel at all of the universities are also contacted in order not to miss any courses, especially those which have recently been developed.

Four employees of the research team at the Danish Foundation for Entrepreneurship - Young Enterprise analyse each course description individually and assess it according to the criteria in the categorisation model. At a minimum two team members assess each course in order to secure an objective categorisation. The course coordinator is contacted in order to double check the evaluation and to assess the number of participants.

The data in this article is analysed with descriptive statistics as there are only eight units of analysis (the eight universities in Denmark), and because we have access to the complete population.

\section{Analysis}

In this section we will present the results of our analysis. We will, however, first start off with a presentation of the Danish context and how it has developed over the past three years, at university level.

\section{The Danish Context}

During the past decade there has been a large variety of state sponsored initiatives in Denmark which all had the goal of initiating more entrepreneurial activities at the universities (Blenker et al., 2006; OECD, 2008). This has led to a significant overlap of activities. In 2010, the Danish government decided instead to channel their resources through one single coordinating organisation which should be responsible for developing entrepreneurship education at all educational levels, 
from $\mathrm{ABC}$ to $\mathrm{PhD}$, so to speak (Danish Agency for Science, Technology and Innovation, 2009). This organisation became the Danish Foundation for Entrepreneurship - Young Enterprise.

The Danish government also decided to allocate 6 million Euros over a three year period for entrepreneurial activities, which was structured as a competing fund which should be granted to the university with the best strategy for transforming into an entrepreneurial university. There were three finalists for the grant. Aarhus University and the University of Southern Denmark applied as single institutions whereas Copenhagen Business School, the Technical University of Denmark and the University of Copenhagen, all located in the capital of Denmark, applied for the grant as a troika. At the end of 2010, Aarhus University won the grant but the Copenhagen troika also was awarded a smaller amount of funding (0.6 million Euros). During 2011 and 2012, the universities have started up their activities.

The Copenhagen troika also managed to get funding from the EU which enabled them to start the initiative Copenhagen Innovation and Entrepreneurship Lab (CIEL). CIEL's goal is to establish a world class entrepreneurial eco-system at the three universities through collaboration at student and teacher level as well as research level and by establishing partnerships with industry (ciellab.dk). At the University of Southern Denmark there is a long standing initiative called the International Danish Entrepreneurship Academy (IDEA). IDEA, which was established in 2005, is a teaching and research oriented entrepreneurship initiative, where industry collaboration is one of the most important ingredients (idea-denmark.dk). The entrepreneurial university initiative at Aarhus University started its activities in 2011 and has a clear goal of establishing AU as the leading entrepreneurial university in Denmark. The focus is on establishing entrepreneurship courses at all faculties, which are aligned with the specific context of the faculties' students. Ten new core courses in entrepreneurship shall be established and seven programmes will be tuned 
towards entrepreneurship, by the end of 2013. The focus is just as much on student employability and innovation in established organisations as it is on new venture creation (eship.au.dk).

Other noticeable initiatives at universities in Denmark are the Centre for Social Entrepreneurship (CSE) at Roskilde University which has been operating since 2008 and is focusing on research and education within the field of social entrepreneurship. The centre also has a strong focus on collaboration with the civil society (ruc.dk/cse). At Aalborg University they have just expanded their campus in Copenhagen which started up its activities in the fall of 2012. The goal is to have an extensive focus on entrepreneurship in the educational programmes at this campus (aau-cph.dk).

\section{The Development of Entrepreneurship Education at Denmark's Eight Universities}

In order to analyse how entrepreneurship education has developed at the eight universities in Denmark it is natural to start with looking at the number of courses and participants at each university. This is, however, dependent on the size of the individual university. In table 1 below the number of students attending each university in the semesters of 2009/2010, 2010/2011 and 2011/2012 is presented. In figure 4 and figure 5 the number of entrepreneurship courses and the number of entrepreneurship students for the three years are presented.

[Insert Table 1 here]

[Insert Figure 4 here] 
[Insert Figure 5 here]

We can clearly see that the three universities involved in the competition for the entrepreneurial university grant are well ahead of the other five universities. The highest number of courses is found at Copenhagen Business School (CBS) and the University of Southern Denmark (SDU), closely followed by Aarhus University (AU) (see figure 4). These three universities have increased the amount of courses compared to 2009/2010, but both the University of Southern Denmark and Aarhus University has decreased their number of courses compared to 2010/2011. It is also noticeable that the number of courses at Roskilde University has decreased significantly.

In figure 5 we see that the universities that have experienced the most positive development regarding the number of students attending the courses are the University of Southern Denmark (SDU) and Copenhagen Business School (CBS), which both manage to increase their numbers significantly. At most of the other universities this number has been decreasing. The most significant decrease can be seen at the Technical University of Denmark (DTU) and Roskilde University (RUC). It is also noticeable that the number of participants in entrepreneurship education at Aarhus University, the entrepreneurial university, has decreased. As the universities vary much in size (table 1), we have calculated the percentage of students subject to entrepreneurship education at the eight universities, which is presented in figure 6.

[Insert Figure 6 here]

When we take the number of students of each university into account we see that both the IT University of Copenhagen (ITU) and the Technical University of Denmark (DTU), two rather small 
universities, are doing fairly well, whereas Aarhus University (AU), which is Denmark's $2^{\text {nd }}$ largest university, falls to the level of Roskilde University (RUC) and that the University of Copenhagen (KU) is performing really badly.

In Figure 7 the amount of ECTS credits (the European standard for comparing study achievement), is presented as a measure of how extensive the focus of the entrepreneurship courses are at the eight universities.

[Insert Figure 7 here]

Here we see a rather stable and positive development for most of the universities. It is, however, noticeable that there has been a large decrease of ECTS credits in entrepreneurship at Roskilde University (RUC) and a fairly significant increase at Copenhagen Business School (CBS).

In order to investigate what content the universities are focusing on we have looked at how the individual university has developed in our four content dimensions over the three years. The number is calculated by the percentage of the maximum score the aggregated number of courses can get. In figure 8 the results are presented.

[Insert Figure 8 here]

We clearly see that entrepreneurship and intrapreneurship are dominating the curricula in entrepreneurship education in Denmark, over the more specialized content dimensions finance and law. Copenhagen Business School (CBS) has progressed very positively in all categories. The 
entrepreneurship courses at both the University of Southern Denmark (SDU) and Aarhus University (AU) have a high specialisation in the content categories. We see that most of the universities have either improved or remained stable on the content categories, which is positive as this means that the courses overall have improved and deepened their focus. The exceptions are Roskilde University that has experienced a negative development in all the content categories, and the IT University of Denmark (ITU) and Aalborg University (AAU), that have decreased regarding the content dimensions intrapreneurship and entrepreneurship. It should, however, be said that these universities are fairly small and have a limited number of courses, so a small change in the course supply comes out with a major impact in our model.

In order to analyze how the eight universities have developed regarding pedagogical methods, which also gives us an approximate measure concerning whether the courses are about, through or for entrepreneurship, as well as how well the content is taught, we have looked at each university's aggregated score on our four pedagogical dimensions. In figure 9 the results of this analysis are presented.

[Insert Figure 9 here]

Here we see fairly positive results as more or less all universities have improved in these categories. The pedagogical dimension that seems to be most problematic for the universities is the multidisciplinary dimension. Again, we see that the smaller universities, the IT University of Copenhagen (ITU), Aalborg University (AAU) and especially Roskilde University (RUC), have experienced a negative development on these dimensions. The troika from Copenhagen, i.e. Copenhagen Business School (CBS), the Technical University of Denmark (DTU) and University 
of Copenhagen (KU), have managed to improve their entrepreneurship education on all categories in the pedagogical dimensions.

We have also investigated which stages in the entrepreneurial project that the entrepreneurship courses at our eight universities are focusing on. In figure 10, the results of this analysis are presented.

[Insert Figure 10A here]

[Insert Figure 10B here]

We see clearly that the main focus is on the idea and the beginning stages, which is quite natural as entrepreneurship often is synonymous with start-up activities. However, it is somewhat worrisome that there is such little focus on growth which is a category often emphasized by policy makers (EBST, 2011). Regarding the pedagogical categories we see that these naturally follow the content categories; however, we see that they have developed more positively than the content dimensions regarding the idea and the beginning stages, but decreased more than the content dimensions in the growth and running stages. It seems that the universities thus have had a strong focus on the two first stages in the entrepreneurial project, and that these courses on average are more through and for entrepreneurship, whereas the courses that focus on the later stages are more about entrepreneurship.

In order to analyse if there is a trend of entrepreneurship education developing outside of the business schools in Denmark, which according to Katz (2008), would be a measure of the field reaching maturity, we divided the universities into two groups, those with a business school and 
those without a business school. There are three universities in Denmark that have a business school, Aarhus University (AU), Copenhagen Business School (CBS) and University of Southern Denmark (SDU). Aalborg University (AAU) recently established a management and business department (2011), which is organized as a collaboration between the social science department and the engineering department, but it is still in its developmental phase (www.aau.dk). In figure 11a the aggregated results of figure 4-6 are presented, and in figure $11 \mathrm{~b}$ the aggregated results of figure 8-9 are presented, for the two groups.

[Insert Figure 11A here]

[Insert Figure 11B here]

[Insert Figure 11C here]

Even though the number of courses has decreased slightly at the three universities with business schools, we see that they have increased regarding the number of participants and the amount of ECTS credits. What is also noticeable is that the courses have improved in quality, both regarding content and pedagogical methods. The courses, thus, focus more intensively on the topic and are becoming increasingly for and through entrepreneurship, rather than about entrepreneurship. The development of entrepreneurship education, at the universities without a business school, looks completely the opposite. Even though the number of courses has increased slightly, the amount of ECTS credits and the number of participants at these five universities have decreased. We cannot see any real progress in neither the content nor the pedagogical dimensions, 
rather we see that the intrapreneurship category, a topic that should be especially suitable to universities without a business school, is decreasing.

\section{Discussion and Implications}

Overall, our analysis of the development of entrepreneurship education at the eight universities in Denmark identifies a small but positive development. It looks like the efforts of the Danish government to transfer the country's universities into entrepreneurial institutions through educational development are working. Our categorization model gives us a good overview of how the field has developed at the individual university and it enables us to identify strengths and weaknesses. It is positive to see that the universities are developing regarding pedagogical methods, as this implies that the courses are focusing more on teaching through and for entrepreneurship rather than about entrepreneurship. The analysis does, however, show that a couple of the universities, especially the smaller ones, have developed negatively, i.e. they have not been able to sustain the supply of entrepreneurship courses.

The development of entrepreneurship education at universities with a business school compared to the universities without a business school looks very different. Regarding the question posed by Katz (2008), if the next paradigm of entrepreneurship education is developing outside of the business school, this does not seem to be the case in Denmark. What this implies is that the field is far from being mature in Denmark. As the field is still in its early stage we are bound to see a dynamic development with new course content and pedagogical methods being tested and restructured. Endurance is of importance in this process. It is clear that the government of Denmark with their investment in entrepreneurship education recognizes that the field of entrepreneurship has its roots in education and that innovation in established organisations is just as important as new 
venture creation. However, it is important to recognize that we need to focus on the sustainability of the field and not just the development of new courses and programmes in the short run. Development of education takes a long time and the real results only materialise in the long run. The data presented in our analysis show that the universities without business schools seem to be struggling with sustaining the supply of courses. This is a challenge that needs to be solved.

The three universities that have developed most positively regarding entrepreneurship education in Denmark are the universities at which a business school is located. It is also these three universities that participated in the competition for the entrepreneurial university grant. Our analysis shows that the initiative called the Copenhagen Innovation and Entrepreneurship Lab (CIEL) might be a way to develop and sustain entrepreneurship education at the weaker (regarding entrepreneurship education) universities. There is a lot of potential in using Copenhagen Business School's knowledge within the field in order to develop the field at the other two partnering universities, the Technical University of Denmark and the University of Copenhagen. CIEL has, however, just recently started up its activities, but it will be interesting to follow what effect this will have in later surveys, especially at the University of Copenhagen which is the largest university in Denmark and which today has very little focus on entrepreneurship education.

The result of our analysis also supports the choice of Aarhus University as the future entrepreneurial university of Denmark. We see that the development of entrepreneurship education at Aarhus University has been fairly stable even though the number of courses and participants has decreased slightly; they have managed to improve the courses regarding content and teaching methods. The results in figure 6 show that there is great potential to increase the number of students targeted by entrepreneurship education at this university, as it is Denmark's second-largest university and fewer than five percent of the students are presently involved in entrepreneurship education. We cannot see any positive results of the entrepreneurial university initiative yet 
regarding entrepreneurship education, but as the strategy is very clear on what will be accomplished by the end of 2013, it will be interesting to see how the university has developed by the next year. Hopefully, they will be able to sustain the courses they already have and not just replace them with newly developed ones.

Our categorisation model has proven to be an effective assessment tool when evaluating the supply of entrepreneurship education on an aggregate level at universities. It gives us a good image of how the field has developed both regarding content, focus on different stages in the entrepreneurial project and which pedagogical methods that have been used. The assessment of teaching methods is especially important as it gives us a good image of whether the courses are about, for or in entrepreneurship.

\section{Concluding Remarks and Suggestions for Future Research}

The investments of the Danish government in entrepreneurship education as a means to transforming the universities into entrepreneurial institutions are moving in the right direction. Our analysis shows that the universities that received the latest government investment have developed positively and have great future potential within the field, but the real results have yet to materialise. The entrepreneurship education field in Denmark is far from mature as our analysis shows that the universities with a business school are far ahead within the field compared to universities without a business school. The smaller universities are struggling with sustaining their supply of entrepreneurship education, and our results show that it is just as important to focus on how to solve this problem as it is to develop new courses and programmes.

Our assessment model of entrepreneurship education has proven to be an effective tool in analysing the supply of courses and programmes on an aggregated level. As the model has its roots 
in the systems of innovation literature it takes a holistic and systemic approach to entrepreneurship education. It can, thus, be used by policy makers who wish to assess where investments in the field will have largest effects, as it reveals potential gaps in the supply of entrepreneurship education. The model can also be used to assess single programmes regarding strengths and weaknesses, in order to understand how to adjust the courses involved. In order to assess entrepreneurship education at other levels of the educational system, it might be the case that the model needs to be altered regarding its content dimensions, but the overall structure should function well whether it is the supply of entrepreneurship education at elementary level or at $\mathrm{PhD}$ level, that is being assessed, as it is both inclusive and specific.

\section{References}

Aldrich, H.E. \& Baker, T. (1997). Blinded by the cites? Has there been progress in the entrepreneurship field? In D. Sexton \& R. Smilor (Eds.), Entrepreneurship 2000 (pp. 377-400). Chicago: Upstart Publishing Company.

Baron, R (2012). Entrepreneurship: An evidence-based guide. Cheltenham, UK, Northhapton, MA, USA, Edward Elgar

Bhave, M.P. (1994). A process model of entrepreneurial venture creation. Journal of Business Venturing, 9(3): 223-242.

Biggs, J. and Tang, C. 2007. Teaching for quality learning at university: What the student does. 3rd ed Open University Press. McGraw Hill. Berkshire.

Blenker, P., Dreisler, P., and Kjeldsen, J. (2006), Entrepreneurship Education - the New Challenge Facing the Universities. A Framework for Understanding and Development of Entrepreneurial University Communities, Working Paper 2006, Aarhus School of Business, Aarhus, p 2.

Block, Z. and MacMillan, I. C. (1993). Corporate Venturing - Creating New Businesses within the Firm. Cambridge, MA.: Harvard Business School Press.

Brush, C. G., I. M. Duhaime, Gartner, W. B, Stewart, ., A., Katz, J. A., Hitt, M. A., Alvarez, S. A., Meyer, G. D., and Venkataraman, S. (2003). "Doctoral Education in the Field of Entrepreneurship," Journal of Management 29(3), 309-331.

Burgelman, R.A. (1983). A Process Model of Internal Corporate Venturing in the Diversified Major Firm. Administrative Science Quarterly. 28: 223-244.

Burgelman, R.A. (1984). Designs for Corporate Entrepreneurship. California Management Review. 26: 154-166

Burgelman, R.A. (1985). Managing the new venture division: Research findings and implications for strategic management. Strategic Management Journal. 6(1): 39-54.

Charney, A., \& Libecap, G.D. 2000.The Impact of Entrepreneurship education: An Evaluation of the Berger Entrepreneurship Programme at the University of Arizona, 1985-99. Tucson: Ewing Marion Kauffman Foundation.

Cooke, P. (2002). Regional Innovation Systems, Clusters and the Knowledge Economy. Industrial and Corporate Change. 6(4): 945-974.

Davidsson, P. (2012). Entrepreneurial Opportunity and the Entrepreneurship Nexus: A Reconceptualization. Conference Paper presented at the Academy of Management Meeting 2012 in Boston.

Davidsson, P. \& Wiklund, J. (2001). Levels of analysis in entrepreneurship research: Current practice and suggestions for the future. Entrepreneurship Theory and Practice, 25(4), 81-99.

Davis, H.G., Diamond, N., 1997. The Rise of American Research Universities: Elites and Challengers in the Post-war Era. Johns Hopkins University Press, Baltimore.

Debackere, K. \& Veugelers, R. (2005). The role of academic technology transfer organizations in improving industry science links. Research Policy 34: 321-342.

EBST (2011). Iværksætterindex 2011 - Vilkår for iværksettere i Denmark. Erhvervs- og Byggestyrelsen.

European Commission (2008). Survey of Entrepreneurship in Higher Education. By: NIRAS Consultants, FORA, ECON Pöyry. 
EC 2011 European university funding and financial autonomy: A study on the degree of diversification of university budget and the share of competitive funding. By: Laura de Dominicis, Susana Elena Pérez, Ana Fernández-Zubieta. EUR 24761 EN - 2011

European Commission (2012). Effects and Impact of Entrepreneurship Programmes in Higher Education. By: DG Enterprise \& Industry, EIM Business \& Policy Research. Gibcus, P., de Kok, J., Snijders, J., Smit L., \& van der Linden, B.

Etzkowitz, H. Webster, A., Gebhardt, C. \& Terra, B.R.C. (2000). The future of the university and the university of the future: evolution of ivory tower to entrepreneurial paradigm. Research Policy 29: 313-330

Etzkowitz, H. (2003). Research groups as 'quasi-firms': the invention of the entrepreneurial university. Research Policy 32:109-121

Foss, N.J. \& Klein, P.G. (2012). Organizing entrepreneurial judgment: A new approach to the firm. Cambridge University Press.

Foss, N.J. \& Lyngsie, J. (2011). The Emerging Strategic Entrepreneurship Field: Origins, Key Tenets, and Research Gaps. In: Hjorth, D. (ed) Handbook of Organizational Entrepreneurship, Edward Elgar.

Geuna, A., 1998. The internationalization of European universities: a return to medieval roots. Minerva XXXVI (3): 253-270.

Gibb, A.A. 1987. Designing effective programmes for encouraging and supplying the business start-up process: Lessons from UK experience", Journal of European Industrial Training, 11 (4): 24-32.

Gibb, A.A. 2002. In pursuit of a new entrepreneurship paradigm for learning: creative destruction, new values, new ways of doing things and new combinations of knowledge. International Journal of Management Reviews, 4 (3): 233-69.

Gibb, A.A. 2011. Concepts into practice: meeting the challenges of development of entrepreneurship educators around an innovative paradigm - The case of International Entrepreneurship Educators' Programme (IEEP). International Journal of Entrepreneurial Behaviour \& Research, 17 (2): 146-165

Hannon, P. (2005), 'Philosophies of enterprise and entrepreneurship education and challenges for higher education in the UK', International Journal of Entrepreneurship and Innovation, 6, No 2, pp 105-114.

Heinonen, J. \& Hytti, U. (2010). Back to Basic: The Role of Teaching in Developing the Entrepreneurial University. Entrepreneurship and Innovation, 11(4): 283-292.

Hitt, M.A., Ireland, R.D., Camp, S.M. \& Sexton, D.L. (2001). Guest Editors, Introduction to the Special Issue. Strategic Entrepreneurship: Entrepreneurial Strategies for Wealth Creation. Strategic Management Journal. 22: 479-491.

Hytti, U. \& O'Gorman, C. (2004). What is "Enterprise Education"? An Analysis of the Objectives and Methods of Enterprise Education Programmes in Four European Countries. Education + Training, 46: 11-23.

Jensen, R.A., Thursby, J.G., Thursby, M.C. (2003). Disclosure and licensing of university inventions. NBERWorking Paper 9734.

Johannisson, B. (1991). University training for entrepreneurship: Swedish approaches. Entrepreneurship and Regional development, 3(1): 67-82.

Jonsson, C. \& T. Jonsson 1998. Entrepreneurial Learning - an Informed Way of Learning: The Case of Enterprising and Business Development, Växjö University.

Katz, J.A. (1994). (1994). "Growth of Endowments, Chairs, and Programs in Entrepreneurship on the College Campus," in F. Hoy, F., Monroy, T.G., \& Reichert, J. (eds.) The Art and Science of Entrepreneurship Education, Volume 1. Cleveland, OH: Baldwin-Wallace College: $127-149$.

Katz, J.A. (2003). "The Chronology and Intellectual Trajectory of American Entrepreneurship Education," Journal of Business Venturing 18: 283-300.

Katz, J.A. (2004) 2004 Survey of Endowed Positions in Entrepreneurship and Related Fields in the United States. Kansas City, MO: Ewing Marion Kauffman Foundation.

Katz, J.A. (2008). Fully Mature but Not Fully Legitimate: A Different Perspective on the State of Entrepreneurship Education. Journal of Small Business Management, 46(4): 550-566.

Klapper, R. \& Neergaard, H. (2012). Five steps to heaven: from student to entrepreneur - an agenda for innovative pedagogy. Conference Paper presented at the European Summer University in Kolding, Denmark, $19^{\text {th }}$ to $25^{\text {th }}$ August, 2012.

Kuratko, D.F. (2005). The Emergence of Entrepreneurship Education: Development, Trends, and Challenges. Entrepreneurship Theory and Practice 29(5): 577-597.

Kyvik, S. (2004). Structural Changes in Higher Education Systems in Western Europe Higher Education in Europe, XXIX ( 3 )

Kyrö P. \& Niemi M. 2007: Advancing Business Planning -From Planning to Entrepreneurial Learning. Blauen G. (ed.) Twente case study-book

Lazear, E.P. (2004). Balanced Skills and Entrepreneurship, American Economic Review, Papers and Proceedings.

Lazear, E.P. (2005). Entrepreneurship', Journal of Labor Economics, 23(4).

Loyens, S.M.M., Magda, J. and Rikers, R.M.J.P. 2008. Self-directed learning I problem-based learning and its relationship with selfregulated learning. Educ Psychol Rev, 20: 411-427.

Lundvall, B- $\AA$. (1992). Introduction. Lundvall, B- $\AA$. (ed.) Towards a Theory of Innovation and Interactive Learning. London; Frances Pinter Publishers Ltd: 1-19.

Mathieu, A., Meyer, M., and van Pottelsberghe de la Potterie, B. (2008). Turning science into business: a case study of a major European research university, Science and Public Policy, 35 (9): 669-679.

McDougall, P.P. and Oviatt, B.M. (2000), "International Entrepreneurship: The Intersection of Two Research Paths", The Academy of Management Journals, 43 (5), pp. 902-906.

McDougall, P.P., Shane, S., and Oviatt, B.M. (1994), "Explaining the Formation of International New Ventures: The Limits of Theories from International Business Research", Journal of Business Venturing 9, pp. 469-487.

Nygaard, C. 2010. A Learning Strategy as a possible vehicle for branding universities? CBS Working paper, CBS Learning Lab

OECD (2001). Benchmarking Industry-Science Relationships, Science, Technology and Industry Outlook 2000. OECD

OECD (2005). University Research Management. Developing Research in New Institutions. OECD.

OECD (2008). Entrepreneurship Review of Denmark. OECD. 
OECD (2009). Evaluation of Programmes Concerning Education for Entrepreneurship, report by the OECD Working Party on SMEs and Entrepreneurship. OECD.

Pittaway, L. \& Cope, J. (2006). Entrepreneurship Education: A Systematic Review of the Evidence. National Council for Graduate Entrepreneurship, Working Paper 002/2006

Pittaway, L. and Cope, J. (2007), "Simulating Entrepreneurial Learning: Integrating Experiental and Collaborative Approaches to Learning". Management Learning 38 (2), pp. 211-233

Politis, D. 2005. Entrepreneurship, career experience and learning: Developing our understanding of entrepreneurship as an experiential learning process, Doktorsavhandling, Ekonomihögskolan vid Lunds Universitet.

Rialp, A., Rialp, J., and Knight, G. A. (2004), "The Phenomenon of Early Internationalizing Firms: What Do We Know after a Decade (1993-2003) of Scientific Inquiry? International Business Review, 14(2), pp. 147-166.

Sarasvathy, S.D. (2004). Making it happen: Beyond theories of the firm to theories of firm design. Entrepreneurship Theory \& Practice, Vol. 28 (6): 519-531.

Sarasvathy, S. (2008). Effectuation: Elements of Entrepreneurial Expertise. UK, Cheltenham: Edward Elgar Publishing Limited

Solomon, G. T. (1979). Small Business Management Resource Guides, Vol. 1-6. Washington, D.C.: U.S. Small Business Administration.

Solomon, G. 2007. An Examination of Entrepreneurship Education in the United States. Journal of Small Business and Enterprise Development. 14: 168-182

Solomon, G. T. \& Fernald, L.W. (1991). Trends in Small Business Management and Entrepreneurship Education in the United States, Entrepreneurship Theory and Practice (15): 25-39.

Solomon, G. T. \& M. Sollosy (1977). Nationwide Survey in Course Offerings in Small Business Management / Entrepreneurship. Washington, D.C.: International Council for Small Business.

Solomon, G. T., Weaver, K.M. \& Fernald, L.W. (1994). Pedagogical Methods of Teaching Entrepreneurship: An Historical Perspective," Gaming and Simulation 25(3): 338-352.

Stevenson, H.H., Roberts, M.J., \& Grousbeck, H.I. (1985). New business ventures and the entrepreneur. Burr Ridge, IL: Richard D. Irwin.

Vesper, K. H. (1985). Entrepreneurship Education 1985. Babson Park, MA: Center for Entrepreneurial Studies, Babson College.

Vesper, K.H. (1993). Entrepreneurship Education 1993. Los Angeles: Entrepreneurial Studies Center, UCLA.

Vesper, K.H. \& Gartner, W.B. (1997) Measuring progress in entrepreneurship education, Journal of Business Venturing, 12 (4): s. 403-21.

Vesper, K.H. \& McMullen, W.E. (1988). Entrepreneurship: Today courses, tomorrow degrees? Entrepreneurship Theory and Practice, 13(1): 7-13.

West, P. G. (2003), "Connecting Levels of Analysis in Entrepreneurship Research: a Focus on Information Processing, Asymmetric Knowledge and Networks, In: Steyaert, C. \& Hjorth, D. (Eds.), New Movements in Entrepreneurship. Edward Elgar, Cheltenham, UK: 51-70.

UNESCO (2004). Changing Structures of the Higher Education Systems: The Increasing Complexity of Underlying Forces. UNESCO Forum Occasional Paper Series Paper No. 6, Diversification of Higher Education and the Changing Role of Knowledge and Research Papers presented at the Second Scientific Committee Meeting for Europe and North America. By: Teichler, $U$.

Zahra, S.A. (1991). Predictors and financial outcomes of corporate entrepreneurship: An exploratory study. Journal of Business Venturing. 14: 451-478.

Zeithaml, C.P. \& Rice, G.H. (1987). Entrepreneurship/Small business education in American universities. Journal of Small Business Management, 25(1), 44-50.

\section{Electronic sources}

Aau-cph.dk. Accessed $9^{\text {th }}$ September, 2012

Ciel-lab.dk. Accessed $9^{\text {th }}$ September, 2012

Eship.au.dk. Accessed $9^{\text {th }}$ September, 2012

Idea-denmark.dk. Accessed $9^{\text {th }}$ September, 2012

Ruc.dk/cse. Accessed $9^{\text {th }}$ September, 2012 


\section{Tables and Figures}

FIGURE 1

The Categorisation Mode

\begin{tabular}{|l|l|l|l|l|l|l|l|}
\hline $\begin{array}{l}\text { Stages/ } \\
\text { Categories }\end{array}$ & $\begin{array}{l}\text { Intrapreneur- } \\
\text { ship }\end{array}$ & $\begin{array}{l}\text { Entrepreneur- } \\
\text { ship }\end{array}$ & $\begin{array}{l}\text { Finance/ } \\
\text { VC }\end{array}$ & Law & $\begin{array}{l}\text { Practical } \\
\text { dimensions }\end{array}$ & $\begin{array}{l}\text { Student } \\
\text { participation }\end{array}$ & $\begin{array}{l}\text { Inter- } \\
\text { disciplinary }\end{array}$ \\
\hline Idea & & & & $\begin{array}{l}\text { International } \\
\text { dimensions }\end{array}$ \\
\hline Beginning & & & & & & & \\
\hline Growth & & & & & & & \\
\hline Running & & & & & & & \\
\hline
\end{tabular}

\section{FIGURE 2}

The Content Dimensions: examples of course content in the different stages

\begin{tabular}{|l|c|c|c|c|}
\hline $\begin{array}{c}\text { Stages/ } \\
\text { Categories }\end{array}$ & Intrapreneurship & Entrepreneurship & Finance/ VC & Law \\
\hline Idea & $\begin{array}{c}\text { Idea generation and } \\
\text { creativity exercises in the } \\
\text { context of established } \\
\text { organisations }\end{array}$ & $\begin{array}{c}\text { Idea generation and } \\
\text { creativity exercises targeted } \\
\text { to new venture creation }\end{array}$ & Financial feasibility plans & Search in patent databases \\
\hline Beginning & $\begin{array}{c}\text { Marshalling of resources; } \\
\text { iterations of new business } \\
\text { ideas; elevator pitches; } \\
\text { business plans }\end{array}$ & $\begin{array}{c}\text { Marshalling of resources; } \\
\text { iterations of new business } \\
\text { ideas; elevator pitches; } \\
\text { business plans }\end{array}$ & $\begin{array}{c}\text { Financial analysis; market } \\
\text { analysis; seed capital }\end{array}$ & $\begin{array}{c}\text { Legal processes related to } \\
\text { start up activity; filing a } \\
\text { patent }\end{array}$ \\
\hline Growth & $\begin{array}{c}\text { Human Resources } \\
\text { Management, }\end{array}$ & $\begin{array}{c}\text { Human Resources } \\
\text { Management, } \\
\text { Internationalisation }\end{array}$ & $\begin{array}{c}\text { Financial analysis for } \\
\text { growth; venture capital; } \\
\text { acquisition }\end{array}$ & $\begin{array}{c}\text { International law, IPR; } \\
\text { employment legislation, in } \\
\text { the context of growing a } \\
\text { venture }\end{array}$ \\
\hline Running & $\begin{array}{c}\text { Continuous innovation, } \\
\text { product diversification and } \\
\text { segmentation }\end{array}$ & $\begin{array}{c}\text { Serial entrepreneurship; } \\
\text { portfolio entrepreneurship; } \\
\text { exit strategies }\end{array}$ & $\begin{array}{c}\text { Financial analysis; } \\
\text { valuating the company; } \\
\text { selling a company; } \\
\text { acquisition }\end{array}$ & $\begin{array}{c}\text { International law, IPR; } \\
\text { employment legislation, in } \\
\text { the context of running a } \\
\text { company }\end{array}$ \\
\hline
\end{tabular}

FIGURE 3

The Content Dimensions

\begin{tabular}{|c|c|c|c|}
\hline Practical dimensions & Student participation & $\begin{array}{c}\text { Interdisciplinary } \\
\text { dimensions }\end{array}$ \\
\hline $\begin{array}{c}\text { Take the students out of the } \\
\text { classroom to the real world or } \\
\text { bring the real world into the } \\
\text { classrooms }\end{array}$ & $\begin{array}{c}\text { Student centered exercises in } \\
\text { order to create active and } \\
\text { responsible learners }\end{array}$ & $\begin{array}{c}\text { Working with the different } \\
\text { disciplinary background of the } \\
\text { students or the teaching } \\
\text { team, or both }\end{array}$ \\
\hline
\end{tabular}


Figure 4

Number of Entrepreneurship courses at the 8 eight universities 2009-2012

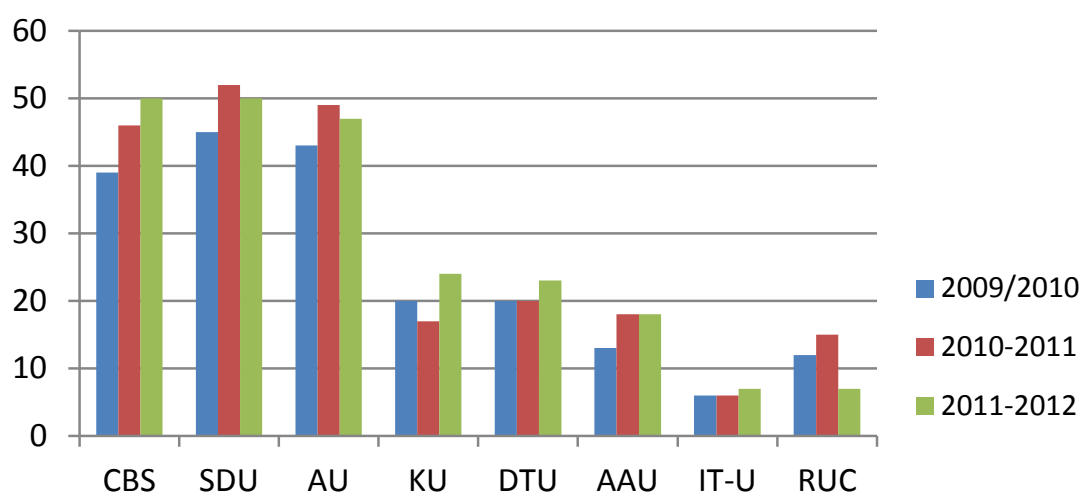

Figure 5

Number of Entrepreneurship students at the 8 eight universities 2009-2012

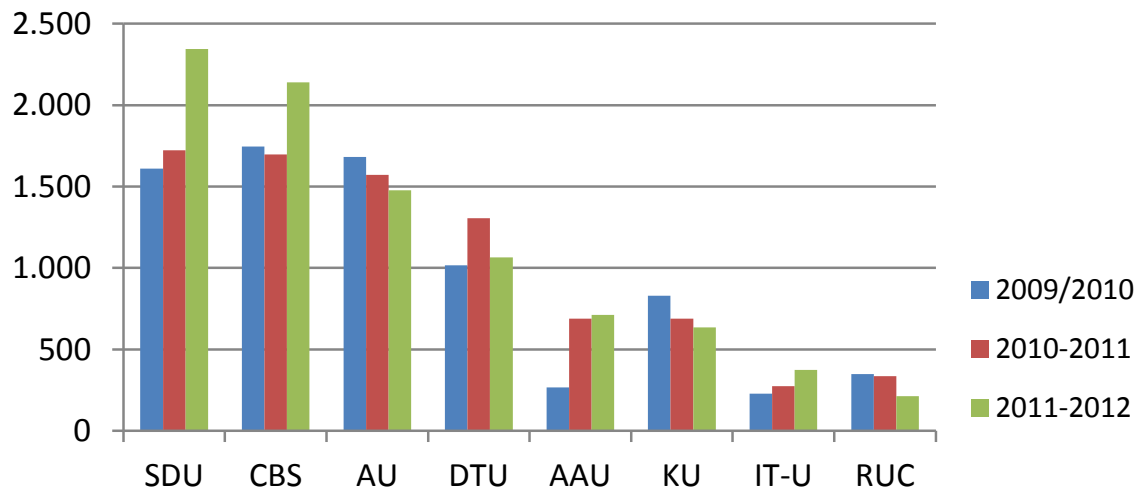

Figure 6

The percentage of entrepreneurship students at Denmark's eight universities 2009- 2012

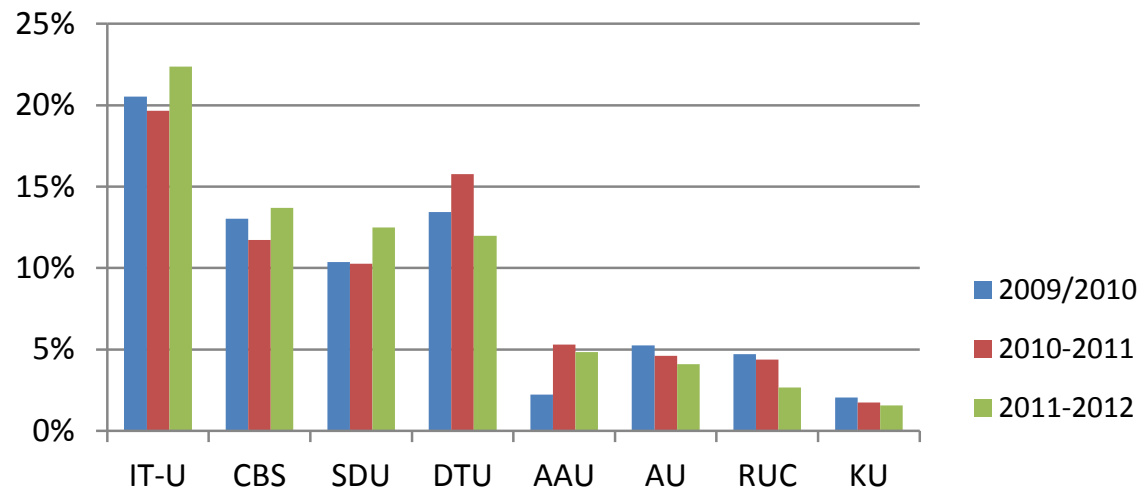


Figure 7

The amount of ECTC credits in entrepreneurship education at Denmark's eight universities 2009 - 2012

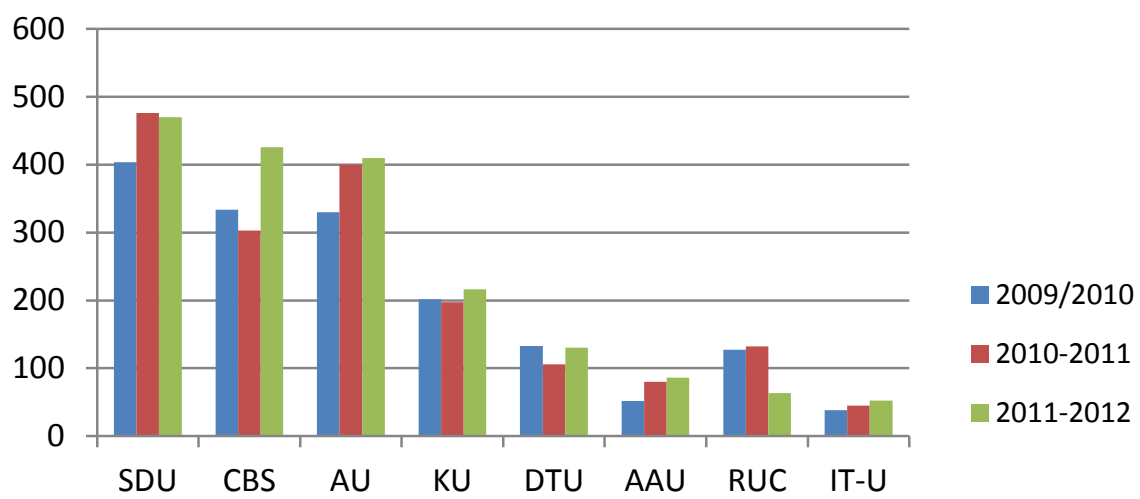

FIGURE 8

How Denmark's eight universities has developed regarding entrepreneurial content dimensions $2009-2012$

Intrapreneurship

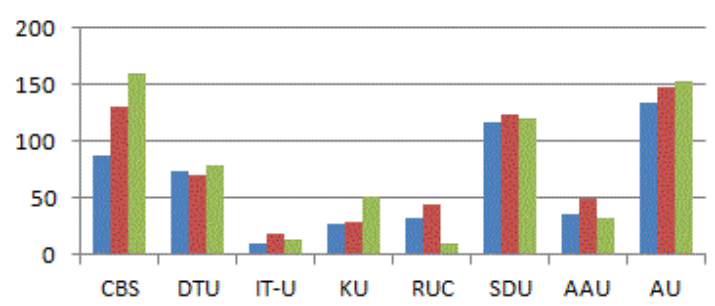

Finance

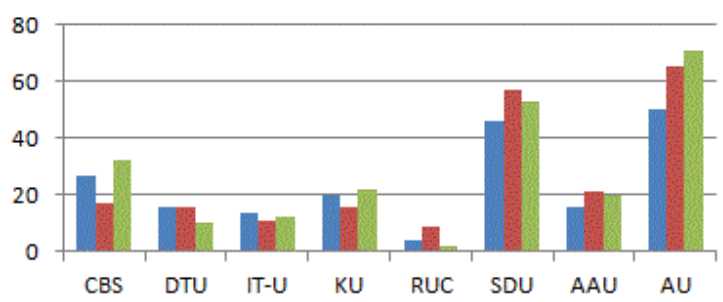

Entrepreneurship

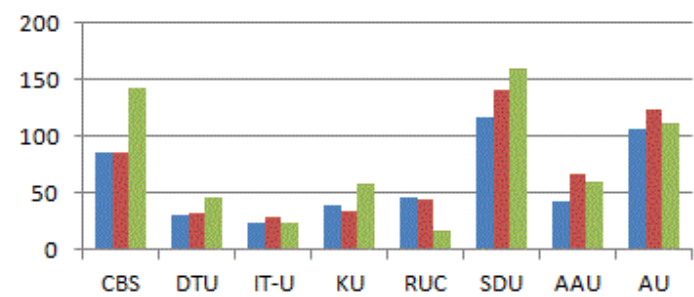

\section{Law}

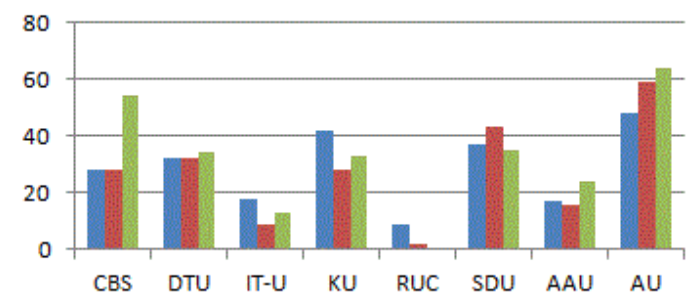

口2009/2010

늘 $2010-2011$

- $2011-2012$ 
FIGURE 9

How Denmark's eight universities has developed regarding entrepreneurial teaching dimensions 2009-2012

Practical Dimensions

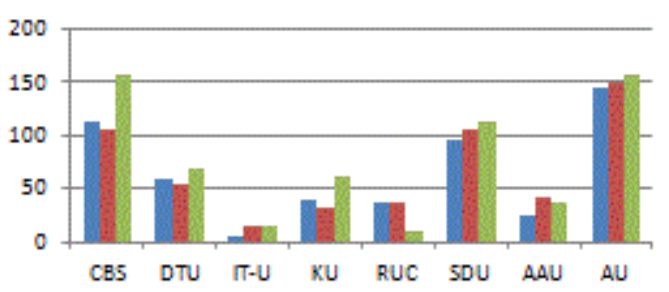

Multidimensionaly Dimensions

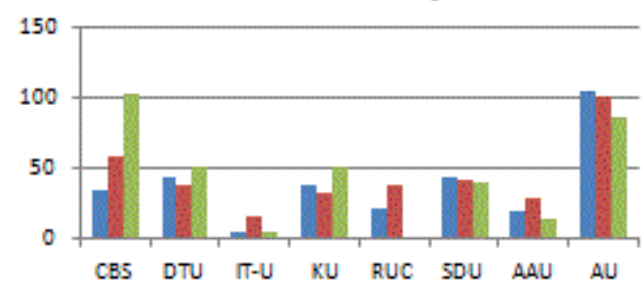

Student Participation

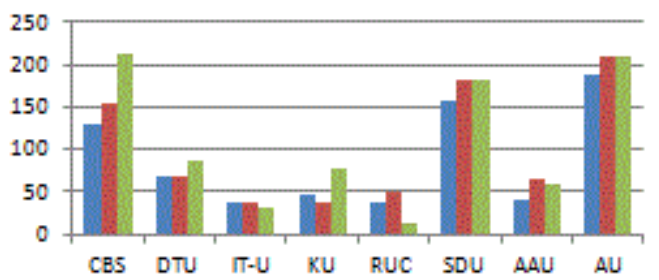

International Dimensions

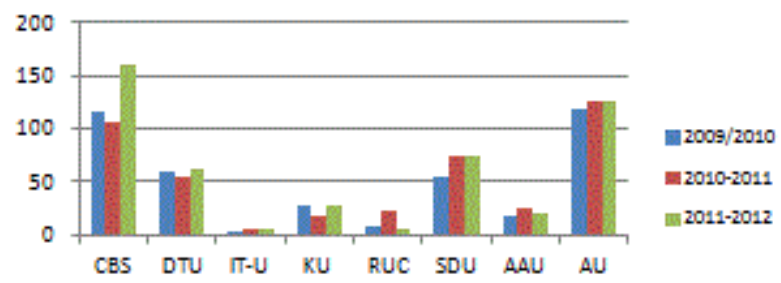

FIGURE 10A:

How Denmark's eight universities has developed regarding stages in the entrepreneurial project 2009 - 2012

Idea / Content

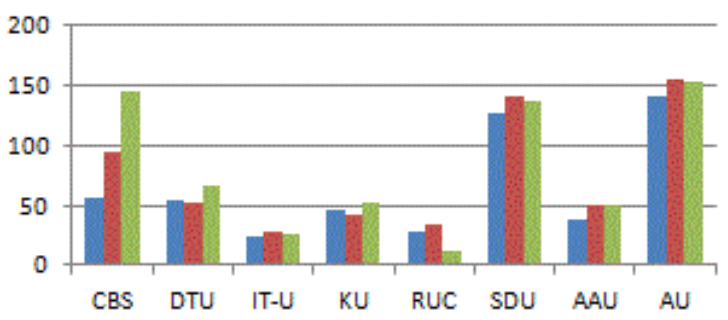

Growth / Content

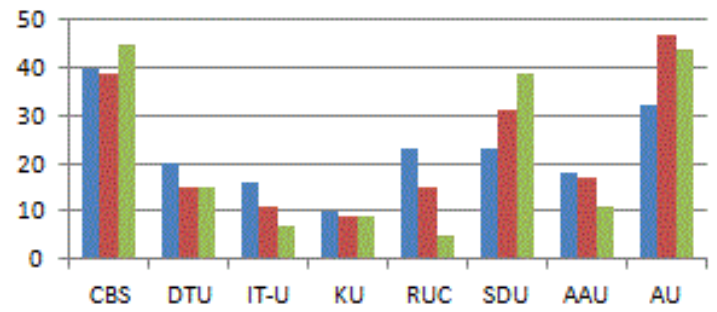

Beginning / Content

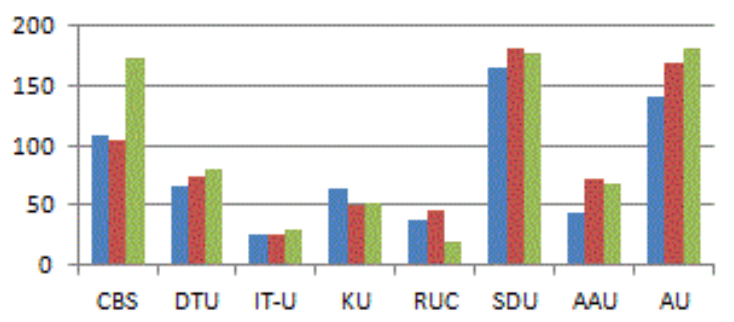

Running / Content

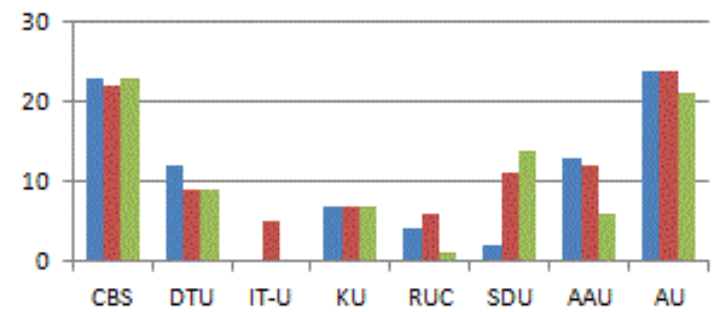


FIGURE 10B

How Denmark's eight universities has developed regarding stages in the entrepreneurial project $2009-2012$
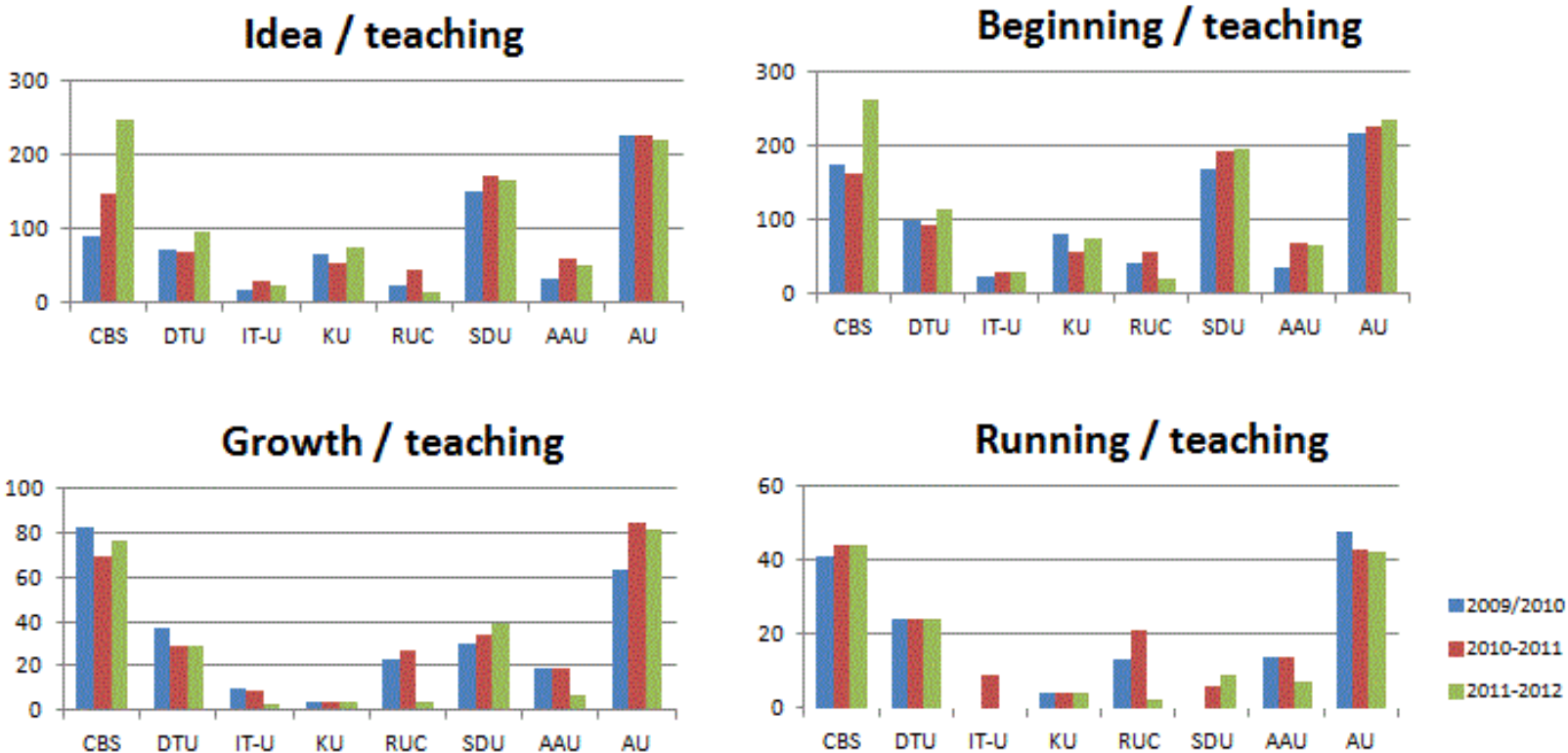
Figure 11A

Courses, ECTS and number of students

Courses

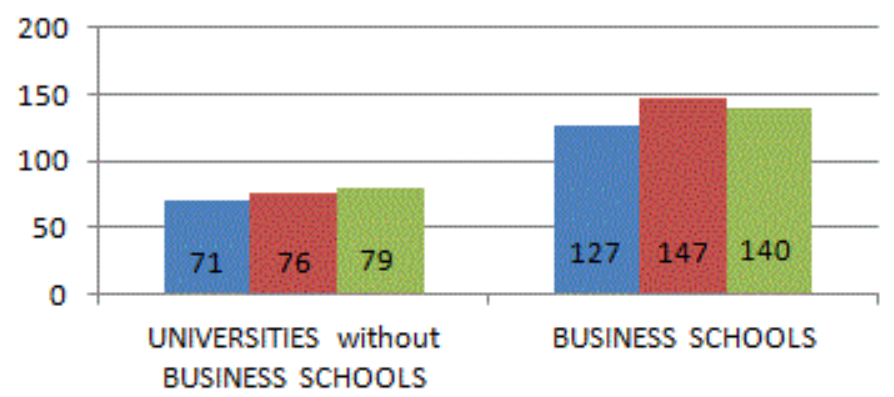

ECTS Credits

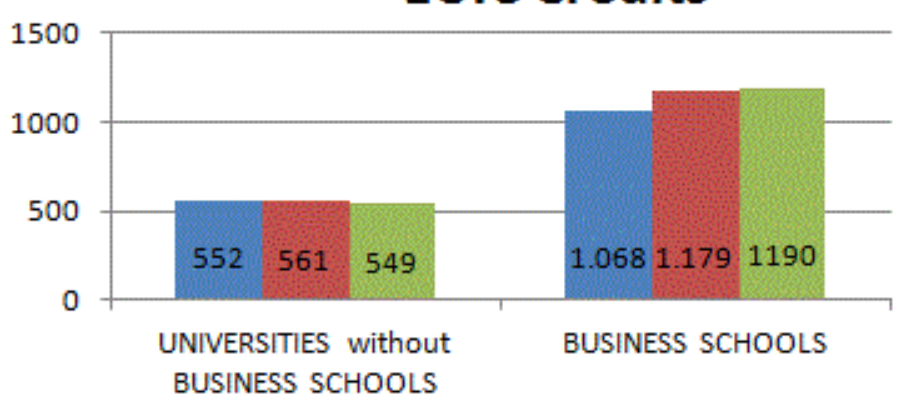

Number of Students

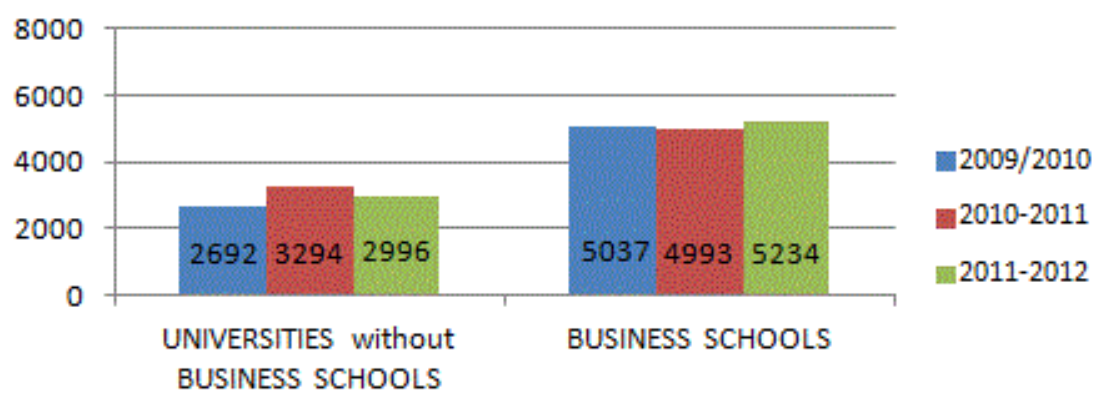


FIGURE 11B

A comparison between Danish universities with and without a business school - Content

Intrapreneurship

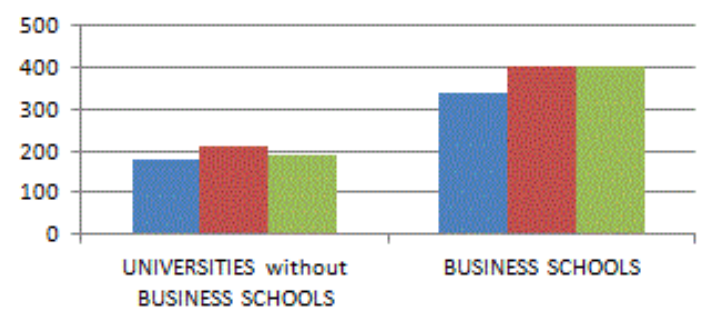

Finance

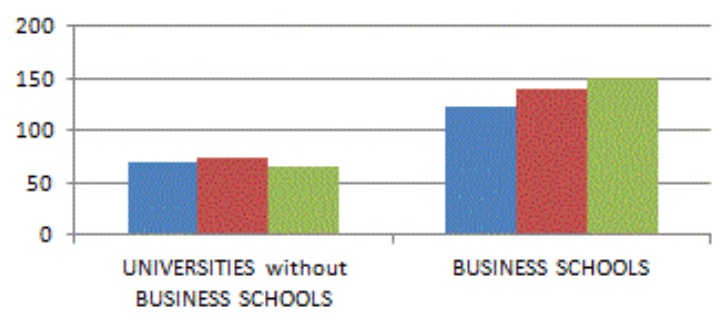

Entrepreneurship

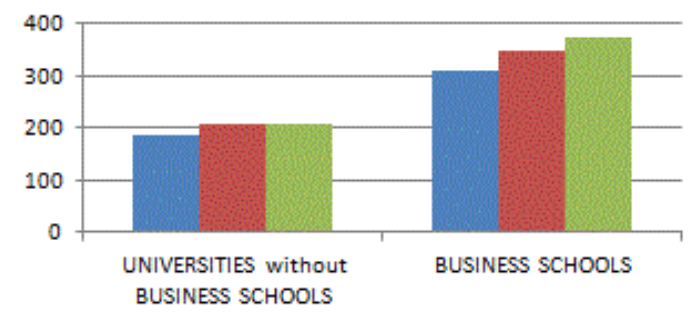

Law

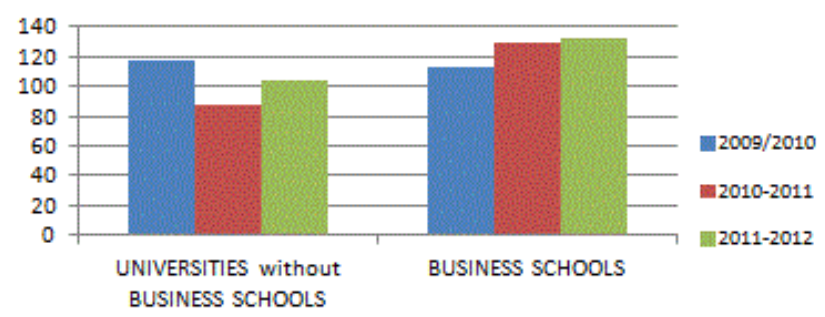

FIGURE 11C

A comparison between Danish universities with and without a business school - Pedagogical dimensions

Practical Dimensions

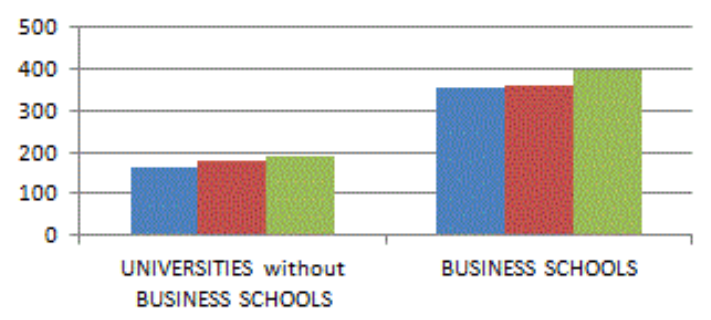

Multidimensionaly Dimensions

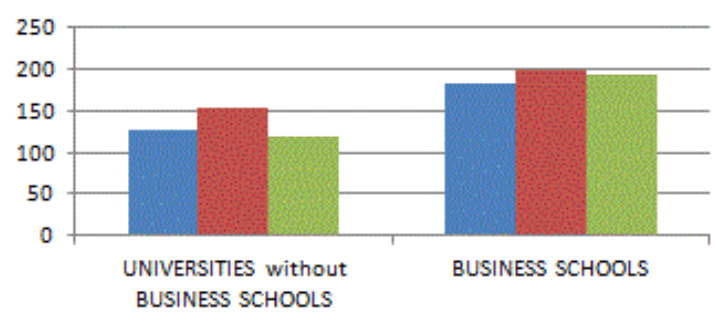

\section{Student Participation}

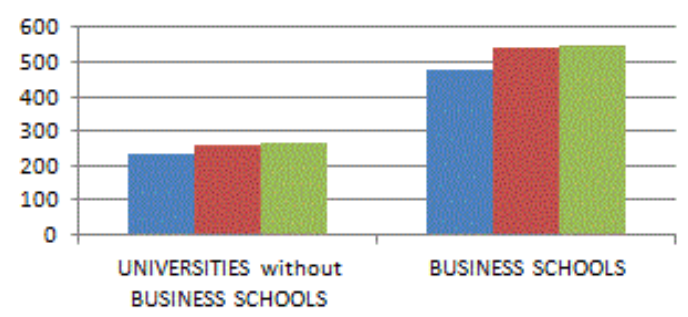

\section{International Dimensions}

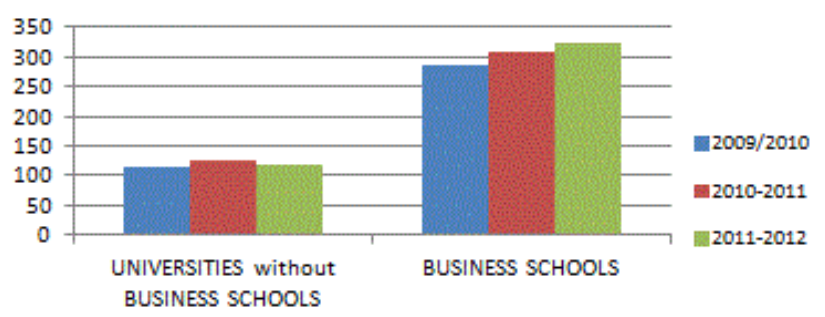




\begin{tabular}{|c|c|c|c|}
\hline $\begin{array}{c}\text { Copenhagen Business School } \\
\text { (CBS }\end{array}$ & $\mathbf{2 0 0 9 / 2 0 1 0}$ & $\mathbf{2 0 1 0 / 2 0 1 1}$ & $\mathbf{2 0 1 1 / 2 0 1 2}$ \\
\hline $\begin{array}{c}\text { Danmarks Tekniske Universitet } \\
\text { (DTU }\end{array}$ & 13.440 & 14.476 & 15.617 \\
\hline IT-Universitetet (IT-U) & 7.608 & 8.269 & 8.873 \\
\hline Københavns Universitet (KU) & 1.116 & 1.398 & 1.667 \\
\hline Roskilde Universitet (RUC) & 70.486 & 39.562 & 40.712 \\
\hline Syddansk Universitet (SDU) & 15.536 & 7.657 & 7.982 \\
\hline Aalborg Universitet (AAU) & 11.959 & 16.760 & 18.763 \\
\hline Aarhus Universitet (AU) & 32.024 & 13.039 & 36.702 \\
\hline In Total & $\mathbf{1 2 9 . 4 7 7}$ & 34.126 & $\mathbf{1 4 4 . 4 0 9}$ \\
\hline
\end{tabular}

Table 1: The number of students enrolled at the eight universities in Denmark, 2009 - 2012 


\section{SMG - Working Papers \\ www.cbs.dk/smg \\ 2003}

2003-1: Nicolai J. Foss, Kenneth Husted, Snejina Michailova, and Torben Pedersen: Governing Knowledge Processes: Theoretical Foundations and Research Opportunities.

2003-2: Yves Doz, Nicolai J. Foss, Stefanie Lenway, Marjorie Lyles, Silvia Massini, Thomas P. Murtha and Torben Pedersen: Future Frontiers in International Management Research: Innovation, Knowledge Creation, and Change in Multinational Companies.

2003-3: Snejina Michailova and Kate Hutchings: The Impact of In-Groups and OutGroups on Knowledge Sharing in Russia and China CKG Working Paper.

2003-4: Nicolai J. Foss and Torben Pedersen: The MNC as a Knowledge Structure: The Roles of Knowledge Sources and Organizational Instruments in MNC Knowledge Management CKG Working Paper.

2003-5: Kirsten Foss, Nicolai J. Foss and Xosé H. Vázquez-Vicente: “Tying the Manager's Hands": How Firms Can Make Credible Commitments That Make Opportunistic Managerial Intervention Less Likely CKG Working Paper.

2003-6: Marjorie Lyles, Torben Pedersen and Bent Petersen: Knowledge Gaps: The Case of Knowledge about Foreign Entry.

2003-7: Kirsten Foss and Nicolai J. Foss: The Limits to Designed Orders: Authority under "Distributed Knowledge" CKG Working Paper.

2003-8: Jens Gammelgaard and Torben Pedersen: Internal versus External Knowledge Sourcing of Subsidiaries - An Organizational Trade-Off.

2003-9: Kate Hutchings and Snejina Michailova: Facilitating Knowledge Sharing in Russian and Chinese Subsidiaries: The Importance of Groups and Personal Networks Accepted for publication in Journal of Knowledge Management.

2003-10: Volker Mahnke, Torben Pedersen and Markus Verzin: The Impact of Knowledge Management on MNC Subsidiary Performance: the Role of Absorptive Capacity CKG Working Paper.

2003-11: Tomas Hellström and Kenneth Husted: Mapping Knowledge and Intellectual Capital in Academic Environments: A Focus Group Study Accepted for publication in Journal of Intellectual Capital CKG Working Paper.

2003-12: Nicolai J Foss: Cognition and Motivation in the Theory of the Firm: Interaction or "Never the Twain Shall Meet"? Accepted for publication in Journal des Economistes et des Etudes Humaines CKG Working Paper.

2003-13: Dana Minbaeva and Snejina Michailova: Knowledge Transfer and Expatriation Practices in MNCs: The Role of Disseminative Capacity.

2003-14: Christian Vintergaard and Kenneth Husted: Enhancing Selective Capacity Through Venture Bases. 


\section{4}

2004-1: Nicolai J. Foss: Knowledge and Organization in the Theory of the Multinational Corporation: Some Foundational Issues

2004-2: Dana B. Minbaeva: HRM Practices and MNC Knowledge Transfer

2004-3: Bo Bernhard Nielsen and Snejina Michailova: Toward a Phase-Model of Global Knowledge Management Systems in Multinational Corporations

2004-4: Kirsten Foss \& Nicolai J Foss: The Next Step in the Evolution of the RBV: Integration with Transaction Cost Economics

2004-5: Teppo Felin \& Nicolai J. Foss: Methodological Individualism and the Organizational Capabilities Approach

2004-6: Jens Gammelgaard, Kenneth Husted, Snejina Michailova: Knowledge-sharing Behavior and Post-acquisition Integration Failure

2004-7: Jens Gammelgaard: Multinational Exploration of Acquired R\&D Activities

2004-8: Christoph Dörrenbächer \& Jens Gammelgaard: Subsidiary Upgrading? Strategic Inertia in the Development of German-owned Subsidiaries in Hungary

2004-9: Kirsten Foss \& Nicolai J. Foss: Resources and Transaction Costs: How the Economics of Property Rights Furthers the Resource-based View

2004-10: Jens Gammelgaard \& Thomas Ritter: The Knowledge Retrieval Matrix: Codification and Personification as Separate Strategies

2004-11: Nicolai J. Foss \& Peter G. Klein: Entrepreneurship and the Economic Theory of the Firm: Any Gains from Trade?

2004-12: Akshey Gupta \& Snejina Michailova: Knowledge Sharing in Knowledge-Intensive Firms: Opportunities and Limitations of Knowledge Codification

2004-13: Snejina Michailova \& Kate Hutchings: Knowledge Sharing and National Culture: A Comparison Between China and Russia

\section{5}

2005-1: Keld Laursen \& Ammon Salter: My Precious - The Role of Appropriability Strategies in Shaping Innovative Performance

2005-2: Nicolai J. Foss \& Peter G. Klein: The Theory of the Firm and Its Critics: A Stocktaking and Assessment

2005-3: Lars Bo Jeppesen \& Lars Frederiksen: Why Firm-Established User Communities Work for Innovation: The Personal Attributes of Innovative Users in the Case of Computer-Controlled Music

2005-4: Dana B. Minbaeva: Negative Impact of HRM Complementarity on Knowledge Transfer in MNCs

2005-5: Kirsten Foss, Nicolai J. Foss, Peter G. Klein \& Sandra K. Klein: Austrian Capital 
Theory and the Link Between Entrepreneurship and the Theory of the Firm

2005-1: Nicolai J. Foss: The Knowledge Governance Approach

2005-2: Torben J. Andersen: Capital Structure, Environmental Dynamism, Innovation Strategy, and Strategic Risk Management

2005-3: Torben J. Andersen: A Strategic Risk Management Framework for Multinational Enterprise

2005-4: Peter Holdt Christensen: Facilitating Knowledge Sharing: A Conceptual Framework

2005-5 Kirsten Foss \& Nicolai J. Foss: Hands Off! How Organizational Design Can Make Delegation Credible

2005-6 Marjorie A. Lyles, Torben Pedersen \& Bent Petersen: Closing the Knowledge Gap in Foreign Markets - A Learning Perspective

2005-7 Christian Geisler Asmussen, Torben Pedersen \& Bent Petersen: How do we Capture "Global Specialization" when Measuring Firms' Degree of internationalization?

2005-8 Kirsten Foss \& Nicolai J. Foss: Simon on Problem-Solving: Implications for New Organizational Forms

2005-9 Birgitte Grøgaard, Carmine Gioia \& Gabriel R.G. Benito: An Empirical Investigation of the Role of Industry Factors in the Internationalization Patterns of Firms

2005-10 Torben J. Andersen: The Performance and Risk Management Implications of Multinationality: An Industry Perspective

2005-11 Nicolai J. Foss: The Scientific Progress in Strategic Management: The case of the Resource-based view

2005-12 Koen H. Heimeriks: Alliance Capability as a Mediator Between Experience and Alliance Performance: An Empirical Investigation Into the Alliance Capability Development Process

2005-13 Koen H. Heimeriks, Geert Duysters \& Wim Vanhaverbeke: Developing Alliance Capabilities: An Empirical Study

2005-14 JC Spender: Management, Rational or Creative? A Knowledge-Based Discussion

\section{6}

2006-1: Nicolai J. Foss \& Peter G. Klein: The Emergence of the Modern Theory of the Firm

2006-2: Teppo Felin \& Nicolai J. Foss: Individuals and Organizations: Thoughts on a Micro-Foundations Project for Strategic Management and Organizational Analysis

2006-3: Volker Mahnke, Torben Pedersen \& Markus Venzin: Does Knowledge Sharing 
Pay? An MNC Subsidiary Perspective on Knowledge Outflows

2006-4: Torben Pedersen: Determining Factors of Subsidiary Development

2006-5 Ibuki Ishikawa: The Source of Competitive Advantage and Entrepreneurial Judgment in the RBV: Insights from the Austrian School Perspective

2006-6 Nicolai J. Foss \& Ibuki Ishikawa: Towards a Dynamic Resource-Based View: Insights from Austrian Capital and Entrepreneurship Theory

2006-7 Kirsten Foss \& Nicolai J. Foss: Entrepreneurship, Transaction Costs, and Resource Attributes

2006-8 Kirsten Foss, Nicolai J. Foss \& Peter G. Klein: Original and Derived Judgement: An Entrepreneurial Theory of Economic Organization

2006-9 Mia Reinholt: No More Polarization, Please! Towards a More Nuanced Perspective on Motivation in Organizations

2006-10 Angelika Lindstrand, Sara Melen \& Emilia Rovira: Turning social capital into business? A study of Swedish biotech firms' international expansion

2006-11 Christian Geisler Asmussen, Torben Pedersen \& Charles Dhanaraj: Evolution of Subsidiary Competences: Extending the Diamond Network Model

2006-12 John Holt, William R. Purcell, Sidney J. Gray \& Torben Pedersen: Decision Factors Influencing MNEs Regional Headquarters Location Selection Strategies

2006-13 Peter Maskell, Torben Pedersen, Bent Petersen \& Jens Dick-Nielsen: Learning Paths to Offshore Outsourcing - From Cost Reduction to Knowledge Seeking

2006-14 Christian Geisler Asmussen: Local, Regional or Global? Quantifying MNC Geographic Scope

2006-15 Christian Bjørnskov \& Nicolai J. Foss: Economic Freedom and Entrepreneurial Activity: Some Cross-Country Evidence

2006-16 Nicolai J. Foss \& Giampaolo Garzarelli: Institutions as Knowledge Capital: Ludwig M. Lachmann's Interpretative Institutionalism

2006-17 Koen H. Heimriks \& Jeffrey J. Reuer: How to Build Alliance Capabilities

2006-18 Nicolai J. Foss, Peter G. Klein, Yasemin Y. Kor \& Joseph T. Mahoney: Entrepreneurship, Subjectivism, and the Resource - Based View: Towards a New Synthesis

2006-19 Steven Globerman \& Bo B. Nielsen: Equity Versus Non-Equity International Strategic Alliances: The Role of Host Country Governance

\section{7}

2007-1 Peter Abell, Teppo Felin \& Nicolai J. Foss: Building Micro-Foundations for the Routines, Capabilities, and Performance Links 
2007-2 Michael W. Hansen, Torben Pedersen \& Bent Petersen: MNC Strategies and Linkage Effects in Developing Countries

2007-3 Niron Hashai, Christian G. Asmussen, Gabriel R.G. Benito \& Bent Petersen: Predicting the Diversity of Foreign Entry Modes

2007-4 Peter D. Ørberg Jensen \& Torben Pedersen: Whether and What to Offshore?

2007-5 Ram Mudambi \& Torben Pedersen: Agency Theory and Resource Dependency Theory: Complementary Explanations for Subsidiary Power in Multinational Corporations

2007-6 Nicolai J. Foss: Strategic Belief Management

2007-7 Nicolai J. Foss: Theory of Science Perspectives on Strategic Management Research: Debates and a Novel View

2007-8 Dana B. Minbaeva: HRM Practices and Knowledge Transfer in MNCs

2007-9 Nicolai J. Foss: Knowledge Governance in a Dynamic Global Context: The Center for Strategic Management and Globalization at the Copenhagen Business School

2007-10 Paola Gritti \& Nicolai J. Foss: Customer Satisfaction and Competencies: An Econometric Study of an Italian Bank

2007-11 Nicolai J. Foss \& Peter G. Klein: Organizational Governance

2007-12 Torben Juul Andersen \& Bo Bernhard Nielsen: The Effective Ambidextrous Organization: A Model of Integrative Strategy Making Processes.

\section{8}

2008-1 Kirsten Foss \& Nicolai J. Foss: Managerial Authority When Knowledge is Distributed: A Knowledge Governance Perspective

2008-2 Nicolai J. Foss: Human Capital and Transaction Cost Economics.

2008-3 Nicolai J. Foss \& Peter G. Klein: Entrepreneurship and Heterogeneous Capital.

2008-4 Nicolai J. Foss \& Peter G. Klein: The Need for an Entrepreneurial Theory of the Firm.

2008-5 Nicolai J. Foss \& Peter G. Klein: Entrepreneurship: From Opportunity Discovery to Judgment.

2008-6 Mie Harder: How do Rewards and Management Styles Influence the Motivation to Share Knowledge?

2008-7 Bent Petersen, Lawrence S. Welch \& Gabriel R.G. Benito: Managing the Internalisation Process - A Theoretical Perspective.

2008-8 Torben Juul Andersen: Multinational Performance and Risk Management Effects: Capital Structure Contingencies. 
2008-9 Bo Bernard Nielsen: Strategic Fit and the Role of Contractual and Procedural Governance in Alliances: A Dynamic Perspective.

2008-10 Line Gry Knudsen \& Bo Bernhard Nielsen: Collaborative Capability in R\&D Alliances: Exploring the Link between Organizational and Individual level Factors.

2008-11 Torben Juul Andersen \& Mahesh P. Joshi: Strategic Orientations of Internationalizing Firms: A Comparative Analysis of Firms Operating in Technology Intensive and Common Goods Industries.

2008-12 Dana Minbaeva: HRM Practices Affecting Extrinsic and Intrinsic Motivation of Knowledge Receivers and their Effect on Intra-MNC Knowledge Transfer.

2008-13 Steen E. Navrbjerg \& Dana Minbaeva: HRM and IR in Multinational Corporations: Uneasy Bedfellows?

2008-14 Kirsten Foss \& Nicolai J. Foss: Hayekian Knowledge Problems in Organizational Theory.

2008-15 Torben Juul Andersen: Multinational Performance Relationships and Industry Context.

2008-16 Larissa Rabbiosi: The Impact of Subsidiary Autonomy on MNE Knowledge Transfer: Resolving the Debate.

2008-17 Line Gry Knudsen \& Bo Bernhard Nielsen: Organizational and Individual Level Antecedents of Procedural Governance in Knowledge Sharing Alliances.

2008-18 Kirsten Foss \& Nicolai J. Foss: Understanding Opportunity Discovery and Sustainable Advantage: The Role of Transaction Costs and Property Rights.

2008-19 Teppo Felin \& Nicolai J. Foss: Social Reality, The Boundaries of Self-fulfilling Prophecy, and Economics.

2008-20 Yves Dos, Nicolai J. Foss \& José Santos: A Knowledge System Approach to the Multinational Company: Conceptual Grounding and Implications for Research

2008-21 Sabina Nielsen \& Bo Bernhard Nielsen: Why do Firms Employ foreigners on Their Top Management Teams? A Multi-Level Exploration of Individual and Firm Level Antecedents

2008-22 Nicolai J. Foss: Review of Anders Christian Hansen's “Uden for hovedstrømmen - Alternative strømninger i økonomisk teori"

2008-23 Nicolai J. Foss: Knowledge, Economic Organization, and Property Rights

2008-24 Sjoerd Beugelsdijk, Torben Pedersen \& Bent Petersen: Is There a Trend Towards Global Value Chain Specialization? - An Examination of Cross Border Sales of US Foreign Affiliates 
2008-25 Vikas Kumar, Torben Pedersen \& Alessandro Zattoni: The performance of business group firms during institutional transition: A longtitudinal study of Indian firms

2008-26 Sabina Nielsen \& Bo B. Nielsen: The effects of TMT and Board Nationality Diversity and Compensation on Firm Performance

2008-27 Bo B. Nielsen \& Sabina Nielsen: International Diversification Strategy and Firm Performance: A Multi-Level Analysis of Firm and Home Country Effects

\section{9}

2009-1 Nicolai J. Foss: Alternative Research Strategies in the Knowledge Movement: From Macro Bias to Micro-Foundations and Multi-Level Explanation

2009-2 Nicolai J. Foss \& Peter G. Klein: Entrepreneurial Alertness and Opportunity Discovery: Origins, Attributes, Critique

2009-3 Nicolai J. Foss \& Dana B. Minbaeva: Governing Knowledge: The Strategic Human Resource Management Dimension

2009-4 Nils Stieglitz \& Nicolai J. Foss: Opportunities and New Business Models: Transaction Cost and Property Rights Perspectives on Entrepreneurships

2009-5 Torben Pedersen: Vestas Wind Systems A/S: Exploiting Global R\&D Synergies

2009-6 Rajshree Agarwal, Jay B. Barney, Nicolai J. Foss \& Peter G. Klein: Heterogeneous Resources and the Financial Crisis: Implications of Strategic Management Theory

2009-7 Jasper J. Hotho: A Measure of Comparative Institutional Distance

2009-8 Bo B. Nielsen \& Sabina Nielsen: The Impact of Top Management Team Nationality Diversity and International Experience on Foreign Entry Mode

2009-9 Teppo Felin \& Nicolai Juul Foss: Experience and Repetition as Antecedents of Organizational Routines and Capabilities: A Critique of Behaviorist and Empiricist Approaches

2009-10 Henk W. Volberda, Nicolai J. Foss \& Marjorie E. Lyles: Absorbing the Concept of Absorptive Capacity: How To Realize Its Potential in the Organization Field

2009-11 Jan Stentoft Arlbjørn, Brian Vejrum Wæhrens, John Johansen \& Torben Pedersen: Produktion i Danmark eller offshoring/outsourcing: Ledelsesmæssige udfordringer 


\section{0}

2010-1 Dana B. Minbaeva, Kristiina Mäkelä \& Larissa Rabbiosi: Explaining Intraorganizational Knowledge Transfer at the Individual Level

2010-2 Dana B.Minbaeva \& Torben Pedersen: Governing Individual Knowledge Sharing Behavior

2010-3 Nicolai J. Foss \& Peter G. Klein: Alertness, Judgment, and the Antecedents of Entrepreneurship

2010-4 Nicolai J.Foss \& Joseph T.Mahoney: Exploring Knowledge Governance

2010-5 Jasper J. Hotho, Florian Becker-Ritterspach \& Ayse Saka-Helmhout: Enriching Absorptive Capacity Through Social Interaction

2010-6 Nicolai J. Foss \& Bo B. Nielsen: Researching Collaborative Advantage: Some Conceptual and Multi-level Issues

2010-7 Nicolai J. Foss \& Nils Stieglitz: Modern Resource-Based Theory(ies)

2010-8 Christian Bjørnskov \& Nicolai J. Foss: Do Economic Freedom and Entrepreneurship Impact Total Factor Productivity?

2010-9 Gabriel R.G. Benito, Bent Petersen \& Lawrence S. Welch: Mode Combinations and International Operations: Theoretical Issues and an Empirical Investigation

\section{1}

2011-1 Peter D. Ørberg Jensen \& Bent Petersen: Human Asset Internalization and Global Sourcing of Services - A Strategic Management Analysis on Activity-level

2011-2 Mie Harder: Management Innovation Capabilities: A Typology and Propositions for Management Innovation Research

2011-3 Mie Harder: Internal Antecedents of Management Innovation: The effect of diagnostic capability and implementation capability 
2011-4 Mie Harder: Explaining Management Innovation Pervasiveness: The Role of Internal Antecedents

2011-5 Mie Harder: Internal Determinants of Product Innovation and Management Innovation: The Effect of Diagnostic Capability and Implementation Capability

2011-6 Nicolai J. Foss, Peter G. Klein \& Per L. Bylund: Entrepreneurship and the Economics of the Firm

2011-7 Nicolai J. Foss \& Jacob Lyngsie: The Emerging Strategic Entrepreneurship Field: Origins, Key Tenets and Research Gaps

2011-8 Nicolai J. Foss: Entrepreneurship in the Context of the Resource-based View of the Firm

2011-9 Bent Petersen, Gabriel R.G. Benito, Olesya Dovgan \& Lawrence Welch: Offshore outsourcing: A dynamic, operation mode perspective

2011-10 Bent Petersen, Gabriel R. G. Benito \& Lawrence Welch: Dynamics of Foreign Operation Modes and their Combinations: Insights for International Strategic Management

2011-11 Nicolai J. Foss: Teams, Team Motivation, and the Theory of the Firm

2011-12 Nicolai J. Foss: Knowledge Governance: Meaning, Nature, Origins, and Implications

2011-13 Nicolai J. Foss, Kirsten Foss \& Phillip C. Nell: MNC Organizational Form and Subsidiary Motivation Problems: Controlling Intervention Hazards in the Network MNC

2011-14 Kåre Moberg: Evaluating Content Dimensions in Entrepreneurship Education

\section{2}

2012-1 Nicolai J. Foss, Nicholas Argyres, Teppo Felin \& Todd Zenger: The Organizational Economics of Organizational Capability and Heterogeneity: A Research Agenda 
2012-2 Torben J. Andersen, Carina Antonia Hallin \& Sigbjørn Tveterås: A Prediction Contest: The Sensing of Frontline Employees Against Executive Expectations

2012-3 Peter G. Klein, Jay B. Barney \& Nicolai J. Foss: Strategic Entrepreneurship

2012-4 Kåre Moberg: The Impact of Entrepreneurship Education and Project-based Education on Students' Personal Development and Entrepreneurial Intentions at the Lower Levels of the Educational System: Too Much of Two Good Things?

2012-5 Keld Laursen \& Nicolai J. Foss: Human Resource Management Practices and Innovation

2012-6 Kåre Moberg: An Entrepreneurial Self-Efficacy Scale with a Neutral Wording

\section{3}

2013-1

Nicolai J. Foss, Diego Stea: The Principal's Theory of Mind: The Role of

Mentalizing for Reward Design and Management in Principal-Agent Relations

2013-2 Dana Minbaeva, Chansoo Park \& Ilan Vertinsky: The Influence of Foreign Partners' Disseminative Capacities on Knowledge Transfers to International Joint Ventures

2013-3

Nicolai J. Foss \& Peter G. Klein: Hayek and Organizational Studies

2013-4 Kåre Moberg, Lene Vestergaard, Casper Jørgensen, Elisabeth Markussen \& Sose Hakverdyan: How to Assess the Development of Entrepreneurship Education at University Level - the Case of Denmark 
